\title{
RESPON PERTUMBUHAN AKSESI KEMANGI PADA BERBAGAI KOMPOSISI PUPUK NITROGEN ALAMI
}

\section{Growth Response of Basil Accessions on Various Nitrogen Natural Fertilizer Composition}

\author{
Arifah Rahayu ${ }^{1}$, Wini Nahraeni ${ }^{2}$, Nur Rochman $^{2}$, Arif Faturrochman ${ }^{1}$ \\ ${ }^{1}$ Program Studi Agroteknologi Fakultas Pertanian Universitas Djuanda, Jl. Tol Ciawi 1, Bogor \\ 16720 \\ ${ }^{2}$ Program Studi Agribisnis Fakultas Pertanian Universitas Djuanda, Jl. Tol Ciawi 1, Bogor 16720 \\ email: $\underline{\text { arifah.rahayu@unida.ac.id }}$
}

\begin{abstract}
ABSTRAK
Tanaman kemangi tidak hanya bermanfaat sebagai sayuran, tetapi juga memiliki banyak khasiat obat. Hal ini mendorong pengembangan budidaya tanaman kemangi yang ramah lingkungan, antara lain melalui penggunaan pupuk alami. Penelitian ini bertujuan untuk mengetahui respon berbagai aksesi kemangi terhadap komposisi pupuk sumber $\mathrm{N}$ yang berasal dari urine sapi, kompos kipahit dan Urea. Penelitian dilaksanakan dengan rancangan acak lengkap faktorial. Faktor pertama adalah aksesi kemangi, yaitu Kemang, Ciaruten, Cijujug dan Gasol. Faktor kedua kombinasi pupuk N (10 taraf), yaitu $100 \%$ N-Urea, 100\% N-urine sapi, 100\% N-kipahit, 75\% N-Urea+25\% N-urine sapi, $75 \%$ N-Urea+25\% N-kipahit, 50\% N-Urea+50\% N-urine sapi, 50\% N-Urea+50\% kipahit, 25\% NUrea+75\% N-urine sapi, 25\% N-Urea+75\% N-kipahit, $0 \% \mathrm{~N}$-Urea+0\% N-urine sapi+0\% N-kipahit. Dosis pupuk $\mathrm{N}$ yang digunakan adalah $150 \mathrm{~kg} \mathrm{~N} \mathrm{ha}^{-1}$. Hasil penelitian menunjukkan Aksesi kemangi yang menunjukkan pertumbuhan dan produksi yang baik adalah 'Ciaruten' dan 'Gasol'. Aplikasi komposisi pupuk Urea dengan kompos kipahit dan Urea dengan urine sapi menghasilkan pertumbuhan dan produksi lebih baik dibandingkan dengan penggunaan pupuk Urea atau pupuk organik secara tersendiri.
\end{abstract}

Kata kunci: kemangi, urine sapi, kompos kipahit

\begin{abstract}
Basil is not only useful as a vegetable, but also has many medicinal properties. This encourages the development of environmentally friendly basil cultivation, through the use of natural fertilizers. This study aims to determine the response of various basil accessions to the composition of source $N$ fertilizer derived from cow urine, kipahit (Tithonia) compost and Urea. The study was conducted with a factorial completely randomized design. The first factor is the accession of basil, namely Kemang, Ciaruten, Cijujug and Gasol. The second factor is the combination of N fertilizer (10 levels), namely 100\% N-Urea, 100\% N-cow urine, 100\% N-kipahit, $75 \% \mathrm{~N}$-Urea $+25 \% \mathrm{~N}$-cow urine, $75 \% \mathrm{~N}$-Urea $+25 \% \mathrm{~N}$-kipahit, $50 \% \mathrm{~N}$-Urea $+50 \% \mathrm{~N}$-urine cow, 50\% N-Urea $+50 \%$ kipahit, 25\% N-Urea $+75 \% \mathrm{~N}$-cow urine, $25 \% \mathrm{~N}$-Urea $+75 \% \mathrm{~N}$ - kipahit, $0 \% \mathrm{~N}$-Urea $+0 \% \mathrm{~N}$ cow urine $+0 \% \mathrm{~N}$-kipahit. The dosage of $\mathrm{N}$ fertilizer used is $150 \mathrm{~kg} \mathrm{~N} \mathrm{ha-1.} \mathrm{The} \mathrm{results} \mathrm{showed}$ that the accession of basil which showed good growth and production was 'Ciaruten' and 'Gasol'. The application of Urea fertilizer composition with kipahit compost and Urea with cow urine produces better growth and production compared to the use of Urea fertilizer or organic fertilizer separately.
\end{abstract}

Keywords: basil, cow urine, kipahit compost 


\section{PENDAHULUAN}

Kemangi (Ocimum basilicum L.) tergolong tanaman indigenous yang dicirikan dengan aroma yang kuat. Di daerah tropika, tanaman ini bersifat tahunan, sedangkan di daerah beriklim sedang merupakan tanaman semusim. Daun kemangi digunakan untuk berbagai keperluan, baik untuk kuliner, biofarmaka maupun tanaman hias. Sebagai sayuran, daun kemangi biasa dimakan mentah sebagai lalap atau dicampur dalam masakan untuk menambah aroma. Daun dan bunga kemangi digunakan sebagai obat tradisional untuk tonic (minuman penyegar) dan vermifuge (anti cacing). Teh kemangi baik digunakan untuk mengurangi mual pada awal kehamilan, perut kembung dan disentri. Minyak atsiri kemangi menguntungkan untuk menurunkan kelelahan mental, flu, kontraksi (kram) otot, radang lapisan dalam hidung (rhinitis), sengatan serangga dan gigitan ular (Ahmad Ch et al. 2015). Sebagai tanaman hias, penampilan daun dan bunga kemangi yang beragam, cukup menarik.

Pemanfaatan kemangi sebagai tanaman sayuran dan biofarmaka menuntut dihasilkannya produk yang aman dikonsumsi dan tidak mengandung residu zat berbahaya. Hal ini antara lain diperoleh melalui budidaya yang ramah lingkungan, menggunakan pupuk alami, terutama sumber nitrogen. Sebagai tanaman sayuran daun, kemangi memerlukan unsur $\mathrm{N}$ yang cukup untuk menunjang pertumbuhan vegetatifnya. Penyemprotan pupuk daun nitrogen meningkatkan bobot dan produksi segar kemangi, dan meningkatkan konsentrasi N$\mathrm{NH}_{4}, \mathrm{~N}_{-} \mathrm{NO}_{3}, \mathrm{~K}$ dan Ca dibandingkan dengan tanaman kontrol (Nurzynska-Wierdak
2011). Lebih lanjut Nurzynska-Wierdak (2012) melaporkan bahwa pemberian dosis $\mathrm{N}$ yang terlalu tinggi pada tanaman kemangi menyebabkan penurunan tinggi tanaman, panjang dan lebar daun, sehingga bobot basah dan kering panen tanaman yang dipupuk dengan dosis $\mathrm{N}$ paling rendah dan sedang, lebih tinggi dibandingkan dengan yang diberi dosis tertinggi.

Diantara sumber nitrogen alami yang murah dan mudah didapat adalah urine sapi dan kompos kipahit. Urine sapi mengandung hara yang cukup tinggi, sehingga dapat digunakan sebagai pupuk organik cair. Urine sapi yang disimpan selama 2 minggu mengandung $5.1 \% \mathrm{~N}, 63.33$ ppm P tersedia dan 16.73 ppm K tersedia (Walunguru 2012). Aplikasi urine sapi setara dengan $125 \mathrm{~kg} \mathrm{~N}$. ha ${ }^{-1}$ nyata meningkatkan pertumbuhan vegetatif kubis bunga, walaupun karakter morfologi, produksi dan kualitas terbaik diperoleh pada kombinasi $50 \%$ urine sapi dan $50 \%$ Urea, dan $\mathrm{B} / \mathrm{C}$ rasio tertinggi pada aplikasi $125 \mathrm{~kg} \mathrm{~N}$. ha ${ }^{-1}$ urine (Khanal et al. 2011).

Tithonia diversifolia (kipahit) tergolong gulma yang banyak tumbuh di lahan kering. Tanaman ini potensial dijadikan pupuk organik sumber $\mathrm{N}$, karena mengandung $1.76 \% \mathrm{~N}, 0.82 \% \mathrm{P}, 3.92 \% \mathrm{~K}$ dengan C/N 8:1 (Olabode et al. 2017). Pertumbuhan dan produksi terong yang dipupuk dengan $75 \%$ kompos kotoran sapi+ 25\% kipahit tidak berbeda nyata dengan yang diberi pupuk anorganik (Pramudika et al. 2011). Penelitian ini bertujuan untuk mengetahui respon berbagai aksesi kemangi terhadap pemberian berbagai komposisi pupuk nitrogen alami dari urine sapi dan kompos kipahit, dan kemungkinannya sebagai alternatif komplemen atau pengganti Urea.

BAHAN DAN METODE

Penelitian dilakukan pada bulan Juli 2019 sampai dengan Oktober 2019, di Kebun 
Percobaan Universitas Djuanda, Ciawi, Bogor. Bahan tanaman yang digunakan berupa benih kemangi aksesi Kemang, Ciaruten, Cijujug dan Gasol. Bahan lain yang dipakai berupa urine sapi yang telah difermentasi, kompos tanaman kipahit, pupuk Urea, SP-36 dan $\mathrm{KCl}$, polibeg ukuran $12 \mathrm{~cm} \times 20 \mathrm{~cm}$ dan $30 \mathrm{~cm} \times 40 \mathrm{~cm}$, tanah kering dan arang sekam. Alat yang digunakan adalah alat pengolah tanah, instalasi penyiram, timbangan dan oven.

Penelitian ini menggunakan rancangan acak lengkap faktorial. Faktor pertama berupa aksesi kemangi asal Kabupaten Bogor (Kemang, Ciaruten, dan Cijujug) dan asal Cianjur (Gasol). Faktor kedua adalah komposisi pupuk $\mathrm{N}$, yang terdiri atas $100 \% \mathrm{~N}$-Urea, $100 \% \mathrm{~N}$-urine sapi, $100 \%$ N-kipahit, $75 \%$ N-Urea+25\% Nurine sapi, 75\% N-Urea+25\% N-kipahit, 50\% $\mathrm{N}-U$ rea+50\% N-urine sapi, $50 \% \quad \mathrm{~N}$ Urea+50\% kipahit, 25\% N-Urea+75\% Nurine sapi, 25\% N-Urea+75\% N-kipahit, 0\% $\mathrm{N}$-Urea+0\% $\mathrm{N}$-urine sapi+0\% $\mathrm{N}$-kipahit. Dosis pupuk $\mathrm{N}$ yang digunakan adalah 150 $\mathrm{kg} \mathrm{N} \mathrm{ha}{ }^{-1}$. Dosis pupuk kompos kipahit dan urine sapi dihitung berdasarkan kandungan $\mathrm{N}$ yang terdapat pada pupuk tersebut, yaitu 3.90 $\% \mathrm{~N}$ pada kompos kipahit dan $0.4 \% \mathrm{~N}$ pada urine sapi. Dosis rekomendasi pupuk $\mathrm{P}$ dan $\mathrm{K}$ adalah $150 \mathrm{~kg} \mathrm{P}_{2} \mathrm{O}_{5} /$ ha dan $150 \mathrm{~kg} \mathrm{~K}_{2} \mathrm{O} / \mathrm{ha}$. Dosis rekomendasi setara dengan $326 \mathrm{~kg}$ Urea/ha, $417 \mathrm{~kg} \mathrm{SP}-36 / \mathrm{ha}$, dan $250 \mathrm{~kg} \mathrm{KCl} / \mathrm{ha}$ atau $5.2 \mathrm{~g}$ Urea, $6.7 \mathrm{~g} \mathrm{SP}-36,4 \mathrm{~g} \mathrm{KCl}, 64.1 \mathrm{~g}$ kompos kipahit dan $625 \mathrm{ml}$ urine sapi per tanaman. Setiap kombinasi perlakuan diulang tiga kali, dengan empat tanaman tiap satuan percobaan.

Benih kemangi disemai pada bak semai dengan media tanah dan arang sekam (1:1) dan dibumbung (dipindah ke polibeg kecil) pada umur 2 minggu setelah semai (MSS). Bibit kemangi dipindah ke polibeg besar pada umur $4 \mathrm{MSS}$, dengan media tanam sama dengan media semai.
Pemupukan diberikan berdasarkan taraf perlakuan. Pupuk Urea dan urine sapi diberikan secara bertahap. Pupuk Urea diberikan $50 \%$ dosis sebagai pupuk dasar dan $25 \%$ sebagai pupuk susulan pada umur 3 dan 6 minggu setelah tanam (MST). Urine sapi diberikan diberikan sebanyak lima kali pemberian, pada umur 0,2, 4, 6 dan 8 MST, dengan cara diencerkan sampai volume air 1 liter. Pupuk kompos kipahit diberikan seminggu sebelum pindah tanam, sedangkan pupuk SP-36 dan $\mathrm{KCl}$ diberikan $100 \%$ sebagai pupuk dasar.

Kegiatan pemanenan dimulai pada umur 8 MST, panen selanjutnya sampai dengan panen ketiga dilakukan secara kondisional sesuai dengan kesiapan panen yakni sampai panjang tunas baru $\pm 15 \mathrm{~cm}$ untuk setiap aksesinya. Pemanenan akan dilakukan dengan cara memotong bagian pucuk daun atau cabang yang masih muda sepanjang $15 \mathrm{~cm}$.

Peubah yang diamati pada penelitian ini meliputi tinggi tanaman, jumlah daun, luas daun, diameter batang, jumlah tunas, Panjang tunas total, bobot basah dan kering panen. Data dianalisis dengan sidik ragam pada taraf 5\%, dan dilanjutkan dengan uji jarak berganda Duncan (Duncan Multiple Range Test/DMRT) pada taraf 5\%, bila terdapat pengaruh perlakuan.

\section{HASIL DAN PEMBAHASAN \\ Hasil}

Tinggi tanaman, jumlah daun dan luas daun kemangi dipengaruhi oleh aksesi dan komposisi pupuk. Tinggi tanaman kemangi aksesi Kemang nyata lebih besar dibandingkan dengan 'Ciaruten' dan 'Gasol', dan tinggi kedua aksesi ini lebih besar dari 'Cijujug'. Di lain pihak jumlah daun 'Ciaruten' lebih banyak dibandingkan dengan 'Kemang', 'Cijujug' dan 'Gasol'. Aksesi kemangi Gasol memiliki ukuran daun terluas dari ketiga aksesi lainnya (Tabel 1). Hal ini menunjukkan keempat aksesi yang 
dicobakan memiliki karakter morfologi

berbeda (Gambar 1).

Tabel 1. Tinggi tanaman, jumlah daun dan luas daun tanaman kemangi pada umur 5 MST

\begin{tabular}{llll}
\hline Perlakuan & Tinggi tanaman $(\mathbf{c m})$ & Jumlah daun (helai) & Luas daun $\left(\mathbf{c m}^{2}\right)$ \\
\hline Aksesi & & & \\
Kemang & $30.9^{\mathrm{c}}$ & $96.1^{\mathrm{b}}$ & $9.10^{\mathrm{a}}$ \\
Ciaruten & $14.5^{\mathrm{b}}$ & $103.4^{\mathrm{c}}$ & $9.50^{\mathrm{a}}$ \\
Cijujug & $10.1^{\mathrm{a}}$ & $79.2^{\mathrm{a}}$ & $8.61^{\mathrm{a}}$ \\
Gasol & $14.7^{\mathrm{b}}$ & $80.5^{\mathrm{a}}$ & $15.54^{\mathrm{b}}$ \\
Komposisi pupuk & & & \\
$100 \% \mathrm{Ua}$ & $15.8^{\mathrm{ab}}$ & $81.4^{\mathrm{ab}}$ & $10.02^{\mathrm{ab}}$ \\
$100 \% \mathrm{Un}$ & $17.4^{\mathrm{bcd}}$ & $88.9^{\mathrm{bc}}$ & $11.07^{\mathrm{abcd}}$ \\
$100 \% \mathrm{Kp}$ & $20.0^{\mathrm{e}}$ & $93.7^{\mathrm{c}}$ & $9.52^{\mathrm{a}}$ \\
$75 \% \mathrm{Ua}+25 \% \mathrm{Un}$ & $17.2^{\mathrm{cd}}$ & $93.7^{\mathrm{c}}$ & $12.21^{\mathrm{cd}}$ \\
$75 \% \mathrm{Ua}+25 \% \mathrm{Kp}$ & $17.8^{\mathrm{cd}}$ & $89.0^{\mathrm{bc}}$ & $12.95^{\mathrm{d}}$ \\
$50 \% \mathrm{Ua}+50 \% \mathrm{Un}$ & $16.9^{\mathrm{bcd}}$ & $93.1^{\mathrm{c}}$ & $10.87^{\mathrm{abc}}$ \\
$50 \% \mathrm{Ua}+50 \% \mathrm{Kp}$ & $18.6^{\mathrm{de}}$ & $88.8^{\mathrm{bc}}$ & $9.75^{\mathrm{a}}$ \\
$25 \% \mathrm{Ua}+75 \% \mathrm{Un}$ & $16.7^{\mathrm{abc}}$ & $94.6^{\mathrm{c}}$ & $11.75^{\mathrm{bcd}}$ \\
$25 \% \mathrm{Ua}+75 \% \mathrm{Kp}$ & $19.6^{\mathrm{e}}$ & $97.7^{\mathrm{c}}$ & $9.69^{\mathrm{a}}$ \\
Tanpa pupuk & $15.1^{\mathrm{a}}$ & $77.2^{\mathrm{a}}$ & $9.03^{\mathrm{a}}$ \\
\hline
\end{tabular}

Keterangan: Huruf yang sama pada kolom yang sama menunjukkan tidak berbeda nyata menurut uji DMRT pada taraf $5 \%$

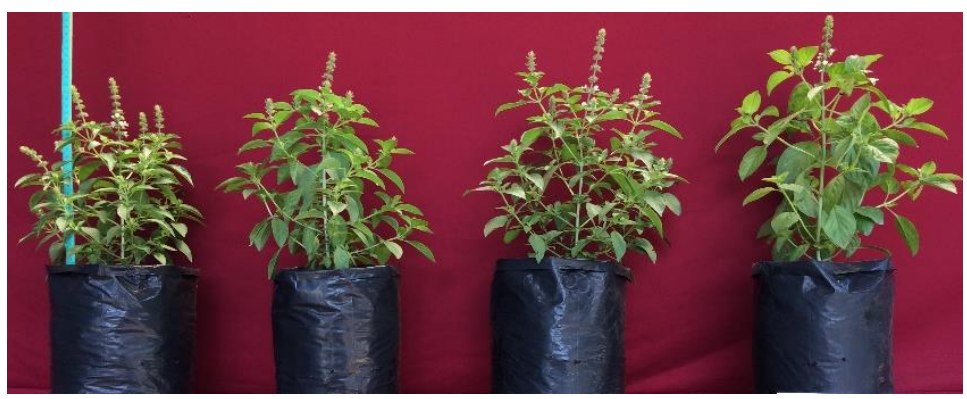

Gambar 1. Penampilan tanaman kemangi, dari kiri ke kanan aksesi Kemang, Ciaruten, Cijujug dan Gasol

Tinggi tanaman kemangi yang dipupuk dengan 100\% kompos kipahit, tidak berbeda nyata dengan yang diberi $25 \%$ Urea $+75 \%$ kompos kipahit dan 50\% Urea $+50 \%$ kompos kipahit, tetapi nyata lebih besar dibandingkan dengan komposisi pupuk lainnya, termasuk dengan yang diberi $100 \%$ Urea. Jumlah daun antar komposisi pupuk relatif tidak berbeda nyata, kecuali dengan yang tidak diberi pupuk dan yang dipupuk $100 \%$ Urea. Luas daun kemangi yang dipupuk dengan $75 \%$ Urea+25\% kompos kipahit tidak berbeda nyata dengan yang diaplikasikan $75 \%$ Urea+25\% urine sapi, $25 \%$ Urea $+75 \%$ urine sapi dan $100 \%$ urine sapi, tetapi nyata lebih luas dibandingkan dengan komposisi pupuk lainnya, termasuk dengan yang diaplikasikan 100\% Urea (Tabel 1).

Jumlah cabang hanya dipengaruhi oleh aksesi. Jumlah cabang tertinggi ditunjukkan oleh kemangi aksesi Ciaruten, yang nyata lebih banyak dibandingkan dengan 'Kemang' dan 'Gasol', sedangkan 
'Cijujug' memiliki jumlah cabang terendah. Panjang cabang total dipengaruhi oleh aksesi dan komposisi pupuk.Aksesi Ciaruten menghasilkan panjang cabang total tertinggi diantara aksesi yang dicobakan (Tabel 2). Aksesi dan komposisi pupuk tidak berpengaruh terhadap diameter batang kemangi. Diameter batang kemangi antara aksesi tidak berbeda nyata (Tabel 2).
Jumlah cabang dan diameter cabang kemangi tidak berbeda antar komposisi pupuk yang diujikan. Demikian pula dengan panjang cabang total, kecuali pada tanaman yang diaplikasikan pupuk Urea $100 \%$ dan yang tanpa pupuk nyata lebih rendah dibandingkan dengan yang diberi 100\% kompos kipahit, $50 \%$ Urea+50\% urine sapi dan $25 \%$ Urea+75\% kompos kipahit (Tabel 2).

Tabel 2. Jumlah cabang, panjang cabang total dan diameter batang tanaman kemangi

\begin{tabular}{llll}
\hline Perlakuan & Jumlah cabang & Panjang cabang total (cm) & Diameter batang (mm) \\
\hline Aksesi & & & \\
Kemang & $16.3^{\mathrm{b}}$ & $133.63^{\mathrm{a}}$ & 6.6 \\
Ciaruten & $19.1^{\mathrm{c}}$ & $152.28^{\mathrm{b}}$ & 6.9 \\
Cijujug & $14.6^{\mathrm{a}}$ & $119.10^{\mathrm{a}}$ & 6.9 \\
Gasol & $16.1^{\mathrm{b}}$ & $118.89^{\mathrm{a}}$ & 8.7 \\
Komposisi pupuk & & & \\
$100 \% \mathrm{Ua}$ & 15.6 & $116.40^{\mathrm{ab}}$ & 7.0 \\
$100 \% \mathrm{Un}$ & 16.6 & $136.88^{\mathrm{bc}}$ & 5.7 \\
$100 \% \mathrm{Kp}$ & 16.5 & $143.90^{\mathrm{c}}$ & 10.1 \\
$75 \% \mathrm{Ua}+25 \% \mathrm{Un}$ & 16.3 & $135.88^{\mathrm{bc}}$ & 7.4 \\
$75 \% \mathrm{Ua}+25 \% \mathrm{Kp}$ & 16.5 & $127.04^{\mathrm{bc}}$ & 7.4 \\
$50 \% \mathrm{Ua}+50 \% \mathrm{Un}$ & 17.1 & $145.51^{\mathrm{c}}$ & 7.2 \\
$50 \% \mathrm{Ua}+50 \% \mathrm{Kp}$ & 16.1 & $134.22^{\mathrm{bc}}$ & 7.7 \\
$25 \% \mathrm{Ua}+75 \% \mathrm{Un}$ & 17.3 & $127.87^{\mathrm{bc}}$ & 7.5 \\
$25 \% \mathrm{Ua}+75 \% \mathrm{Kp}$ & 17.0 & $147.63^{\mathrm{c}}$ & 5.0 \\
Tanpa pupuk & 15.4 & $94.44^{\mathrm{a}}$ &
\end{tabular}

Keterangan: Huruf yang sama pada kolom yang sama menunjukkan tidak berbeda nyata menurut uji DMRT pada taraf $5 \%$

Bobot basah dan kering panen kemangi dipengaruhi oleh aksesi dan komposisi pupuk. Bobot basah panen kemangi aksesi Gasol lebih tinggi dibandingkan dengan 'Kemang' dan 'Cijujug', tetapi tidak berbeda nyata dengan 'Ciaruten'. Sementara itu bobot kering panen kemangi 'Ciaruten' tidak berbeda nyata dengan 'Gasol', tetapi lebih berat dibandingkan dengan 'Kemang' dan 'Cijujug'. Bobot basah dan kering kemangi 'Cijujug' paling ringan dibandingkan ketiga aksesi lainnya (Tabel 3).

Bobot basah dan kering tanaman kemangi yang menggunakan pupuk organik saja (100 $\%$ urine sapi atau $100 \%$ kompos kipahit) tergolong rendah, tidak berbeda nyata dengan yang tidak dipupuk. Di lain pihak bila di kombinasikan dengan Urea, dengan komposisi $25 \%$ Urea $75 \%$ urine sapi atau $75 \%$ kompos kipahit menghasilkan bobot yang beratnya tidak berbeda nyata dengan yang dipupuk 100\% Urea (Tabel 3). 
Tabel 3. Bobot basah dan kering panen per tanaman

\begin{tabular}{lll}
\hline $\begin{array}{l}\text { Perlakuan } \\
\text { Aksesi }\end{array}$ & Bobot basah (g) & Bobot kering (g) \\
\hline Kemang & $80.19^{\mathrm{b}}$ & $12.44^{\mathrm{b}}$ \\
Ciaruten & $92.04^{\mathrm{bc}}$ & $15.94^{\mathrm{c}}$ \\
Cijujug & $61.61^{\mathrm{a}}$ & $9.33^{\mathrm{a}}$ \\
Gasol & $102.75^{\mathrm{c}}$ & $15.36^{\mathrm{bc}}$ \\
Komposisi pupuk & & \\
\hline $100 \% \mathrm{Ua}$ & $105.84^{\mathrm{bc}}$ & $17.08^{\mathrm{c}}$ \\
$100 \% \mathrm{Un}$ & $35.81^{\mathrm{a}}$ & $6.37^{\mathrm{a}}$ \\
$100 \% \mathrm{Kp}$ & $42.73^{\mathrm{a}}$ & $6.93^{\mathrm{a}}$ \\
$75 \% \mathrm{Ua}+25 \% \mathrm{Un}$ & $98.77^{\mathrm{bc}}$ & $15.49^{\mathrm{bc}}$ \\
$75 \% \mathrm{Ua}+25 \% \mathrm{Kp}$ & $79.96^{\mathrm{b}}$ & $11.98^{\mathrm{b}}$ \\
$50 \% \mathrm{Ua}+50 \% \mathrm{Un}$ & $104.77^{\mathrm{bc}}$ & $16.78^{\mathrm{c}}$ \\
$50 \% \mathrm{Ua}+50 \% \mathrm{Kp}$ & $94.72 \mathrm{~b}^{\mathrm{c}}$ & $14.99^{\mathrm{bc}}$ \\
$25 \% \mathrm{Ua}+75 \% \mathrm{Un}$ & $122.04^{\mathrm{c}}$ & $18.13^{\mathrm{c}}$ \\
$25 \% \mathrm{Ua}+75 \% \mathrm{Kp}$ & $115.23^{\mathrm{c}}$ & $17.23^{\mathrm{c}}$ \\
Tanpa pupuk & $46.63^{\mathrm{a}}$ & $7.71^{\mathrm{a}}$ \\
\hline
\end{tabular}

Keterangan: Huruf yang sama pada kolom yang sama menunjukkan tidak berbeda nyata menurut uji DMRT pada taraf $5 \%$

\section{Pembahasan}

Dari empat aksesi yang dicobakan, bobot basah dan kering panen tertinggi dicapai oleh 'Ciaruten' dan 'Gasol'. Hal ini berkaitan dengan perbedaan karakter morfologi antar aksesi. Aksesi kemangi Kemang memiliki tinggi tanaman terbesar, berjumlah daun sedang dan luas daun relatif kecil, sedangkan 'Ciaruten' memiliki tinggi tanaman sedang, jumlah daun paling banyak dengan luas daun relatif kecil. Selain itu 'Ciaruten' memiliki jumlah cabang dan panjang cabang total terbesar. Berbagai karakter 'Ciaruten' yang demikian membuatnya mampu menghasilkan bobot basah dan kering panen yang besar. Sementara itu 'Gasol' menunjukkan tinggi tanaman sedang, jumlah daun sedikit, tetapi luas daun paling besar, ditambah jumlah cabang sedang dan panjang cabang total relatif rendah. Ukuran daun 'Gasol' yang besar, membuatnya menghasilkan bobot basah dan kering panen yang setara dengan 'Ciaruten'. Di lain pihak aksesi kemangi Cijujug menampilkan tinggi tanaman, jumlah daun dan luas daun relatif rendah dibandingkan ketiga aksesi lainnya, demikian pula dengan jumlah cabang dan panjang cabang tunas total, sehingga bobot basah dan kering panennya pun paling rendah,
Pertumbuhan yang ditunjukkan oleh tinggi tanaman, jumlah daun, panjang cabang total tanaman yang tidak diberi pupuk $\mathrm{N}$, baik dalam bentuk Urea, kompos kipahit maupun urine sapi nyata lebih rendah dibandingkan dengan tanaman yang dipupuk N. Hal ini menunjukkan peranan $\mathrm{N}$ yang penting dalam pertumbuhan tanaman kemangi. Nitrogen merupakan unsur hara esensial yang berperan sebagai penyusun asam amino, sehingga otomatis merupakan komponen utama dari protein dan enzim. Peran penting lainnya adalah sebagai penyusun klorofil, yang secara langsung berkaitan denga kemampuan berfotosintesis. Tanaman yang kekurangan unsur $\mathrm{N}$ akan mengalami laju fotosintesis yang lebih rendah, sehingga fotosintat yang dihasilkan juga terbatas, dan berpengaruh pada pertumbuhan vegetatif tanaman. Hasil penelitian (Toungos et al. 2018) menunjukkan peningkatan dosis pupuk $\mathrm{N}$ dari $0 \mathrm{~kg} /$ ha hingga $120 \mathrm{~kg} / \mathrm{ha}$ nyata meningkatkan pertumbuhan tanaman bayam (Amaranthus cruenthus L.), yang ditampilkan oleh lingkar batang, indeks luas daun dan bobot segar per tanaman. Mundiano (2013) menyatakan pemupukan N 
dalam bentuk Urea dengan dosis $200 \mathrm{~kg} / \mathrm{ha}$ nyata meningkatkan pertumbuhan tanaman kemangi, dibandingkan dengan pemberian pupuk kandang sapi, kambing atau ayam dengan dosis 3 ton/ha.

Pada awal pertumbuhan, beberapa peubah (tinggi tanaman, jumlah daun dan panjang cabang) tanaman kemangi yang dipupuk 100\%R kompos kipahit nyata lebih tinggi dibandingkan dengan tanaman yang diberi $100 \% \mathrm{R}$ Urea, tetapi pada akhir penelitian produksi tanaman yang diberi kompos kipahit $100 \% \mathrm{R}$ amat rendah. Diduga hal ini disebabkan sifat kompos kipahit yang mudah terurai dan melepaskan unsur hara N, P dan K (Widiwurjani dan Suhardjono 2006), dan hanya diaplikasikan satu kali, pada waktu seminggu sebelum tanam. Bobot panen tanaman kemangi yang diberi $100 \% \mathrm{R}$ urine sapi juga relatif rendah, berbeda dengan hasil penelitian Aranta (2019), bahwa jumlah cabang, diameter cabang, bobot basah dan kering panen tanaman kemangi yang diberi $100 \%$ R urine sapi lebih besar dibandingkan dengan yang dipupuk 100\% R Urea.

Tanaman kemangi yang dipupuk dengan kombinasi pupuk organik, baik kompos kipahit maupun urine sapi dengan Urea menghasilkan pertumbuhan dan dan produksi lebih baik dibandingkan dengan yang diberi pupuk organik atau Urea secara tersendiri. Hal ini sejalan dengan hasil penelitian Liu et al. (2014), bahwa tanaman selada yang dipupuk dengan kombinasi pupuk organik dan pupuk cair yang diberikan setiap 3-4 hari sekali memiliki panjang daun, lebar daun dan tinggi tajuk lebih besar dibandingkan dengan yang diberi pupuk anorganik (amonium nitrat) atau pupuk organik saja. Hasil yang sama didapat oleh Aranta et al. (2019), pemupukan tanaman kemangi dengan berbagai komposisi Urea dan urine sapi menghasilkan tinggi tanaman, jumlah daun, luas daun dan panjang cabang tidak berbeda nyata dengan yang diberi $100 \%$ R Urea. Hal ini mengindikasikan, bahwa sifat pupuk organik dan sintetik bersifat komplementer. Pupuk organik memiliki kandungan hara jauh lebih rendah dibandingkan dengan pupuk sintetik, tetapi komposisi haranya lebih lengkap dan sering kali mengandung zat pengatur tumbuh. Antonius et al.(2014) melaporkan, bahwa limbah tandan pisang mengandung bakteri yang mampu menghasilkan asam indol asetat (IAA). Keuntungan lainnya pupuk organik tidak hanya memperbaiki sifat kimia melalui peningkatan $\mathrm{pH}$ tanah, tetapi juga biologi tanah (peningkatan populasi mikroba bakteri dan fungi) (Pangaribuan et al. 2018). Lebih lanjut Pangaribuan et al. (2018) melaporkan bahwa kombinasi pupuk organik dengan Urea dapat mengurangi penggunaan pupuk Urea dan meningkatkan tinggi tanamna, indeks luas daun, kandungan klorofil dan karotenoid daun jagung manis.

\section{KESIMPULAN}

Aksesi kemangi yang menunjukkan pertumbuhan dan produksi yang baik adalah 'Ciaruten' dan 'Gasol'. Komposisi pupuk kombinasi antara Urea dengan kompos kipahit dan Urea dengan urine sapi menghasilkan pertumbuhan dan produksi lebih baik dibandingkan dengan penggunaan pupuk Urea atau pupuk organik secara tersendiri.

\section{UCAPAN TERIMA KASIH}

Terima kasih kepada Direktorat Jenderal Pendidikan Tinggi atas batuan hibah penelitian melalui skim Penelitian Terapan Unggulan Perguruan Tinggi (PTUPT) tahun 2019.

\section{DAFTAR PUSTAKA}

Ahmad Ch M, Naz SB, Sharif A, Akram M, Saeed MA. 2015. Biological and pharmaceutical properties of the sweet basil (Ocimum basilicum). Review. 
British J. Pharmaceutical Research 7(5):330-339.

Antonius S, Agustyani D, Imamuddin H, Dewi TK, Laili N. 2014. Kajian bakteri penghasil hormon tumbuh IAA sebagai pupuk organik hayati dan kandungan IAA selama penyimpanan. Prosiding Seminar Nasional Pertanian Organik. Bogor, 18-19 Juni 2014.

Aranta DP, Rahayu A, Mulyaningsih Y. 2019. Pertumbuhan dan produksi aksesi kemangi (Ocimum basilicum L.) pada berbagai komposisi pupuk Urea dan urine sapi. J Agronida 5(1):21-28.

Khanal A, Shakya SM, Shah SC, Sharma MD. 2011. Utilization of urine waste to produce quality cauliflower. J Agric Environt 12:91-96.

Liu CW, Sung Y, Chen BC, Lai HY. 2014. Effects of nitrogen fertilizers on the growth and nitrate content of lettuce (Lactuca sativa L.). Int J Environ Res Public Health 11: 4427-4440.

Mundiano A. 2013. Pengaruh Jenis Pupuk Kandang dan Dosis Pupuk Kimia Nitrogen terhadap Pertumbuhan dan Hasil Tanaman Kemangi. [Thesis]. Yogyakarta: UPN "Veteran".

Nurzynska-Wierdak R, Borowski B, Dzida K. 2011. Yield and chemical composition of basil herb depending on cultivar and foliar feedeing of $\mathrm{N}$. Acta Sci Polonorum Cultus 10(1):2017-219.

Nurzynska-Wierdak R, Rozek E, Dzida K, Borowski B. 2012. Growth response to nitrogen and potassium fertilization of common basil (Ocimum basilicum L.) plants. Acta Sci. Pol. Hortorum Cultus 11(2):275288.

Olabode OS, Sola O, Akanbi WB, Adesina GO, Babajide PA. 2007. Evaluation of Tithonia diversifolia (Hemsl.) A Gray for Soil Improvement. World J Agric Sci 3 (4): 503-507.

Pangaribuan DH, Hendarto K, Elzhivago R, Yulistiani A. 2018. The effect of organic and urea fertilizer on growth and quality of sweet corn and soil health. Asian J Agri \& Biol 6(3):335344.
Pramudika G, Tyasmoro SY, Suminarti NE. 2014. Kombinasi kompos kotoran sapi dan paitan Tithonia diversifolia L.) pada pertumbuhan dan hasil tanaman terung (Solanum melongena L.). J Produksi Tanaman 2( 3): 253259.

Saperstein RL. 2014. Effect of organic nitrogen fertility on yield and nutritional contents of basil and collard green. [Thesis]. Athens, Georgia: The University of Georgia.

Toungos MD, Babayola M, Shehu HE, Kwaga YM, Bamal N. 2018. Effects of nitrogen fertilizer on the growth of vegetable amaranths (Amaranthus cruensis L.) in Mubi, Adamawa State Nigeria. Asian J Advan Agric Res. 6(2):1-12.

Walunguru L. 2012. Kualitas pupuk organik cair dari urine sapi pada beberapa waktu simpan. Partner 19(1):26-32.

Widiwurjani, Suhardjono H. 2006. Respon dua varietas sawi terhadap pemberian biofertilizer Tithonia (Tithonia diversifolia) sebagai pengganti pupuk anorganik. Prosiding Seminar Nasional Bioteknologi dan Pemuliaan Tanaman. Departemen Agronomi dan Hortikultura. Fakultas Pertanian Institut Pertanian Bogor. Bogor 1-2 Agustus 2006. 